\title{
Estimation of the Source Parameters of the Flores Earthquake and Their Correlation to Aftershocks
}

\author{
Emanuel Destianus Banggut ${ }^{1}$, Bagus Jaya Santosa ${ }^{1}$
}

\begin{abstract}
This study uses data provided by BMKG Indonesia which is downloaded from the website www.webdc.eu. The data processing is done by using some software, one of them is Matlab to run Isola software. The software provides information about the fault direction. In addition, this study also uses Coulomb 3.3 software to provide information on subsequent earthquake forecasts. The results showed that the earthquake that occurred on 27th February 2015 gave impact to Coulomb's increase and decrease of stress to some areas in the northern mainland of Flores. The impact of this major earthquake is expected to trigger an earthquake that occurred in northern Flores. Based on the results of data processing obtained form focal mechanism is oblique reverse with the first nodal value strike 139 , dip 73 , and rake 50 . While on the second nodal has a strike value 30, dip 43, and rake 154. Main earthquake impact Coulomb stress increase of 0.15-0.2 bar. Meanwhile, Coulomb stress result obtained shear value $\mathbf{- 1 8 . 8 9 0}$, normal $\mathbf{- 0 . 2 1 7}$, and Coulomb $\mathbf{- 1 9 . 9 7 6}$.
\end{abstract}

Keywords—Strike, Dip, Rake, Fault Direction

\section{INTRODUCTION}

$\mathrm{F}$ lores island is one of the mainland in the East Nusa Tenggara Islands, which belongs to the small Sunda Islands group with Bali and NTB, with an area of about $14,300 \mathrm{~km} 2$, located at $123^{\circ} 25^{\prime}-127^{\circ} 19$ 'East Longitude $8^{\circ} 17^{\prime}-10^{\circ} 22^{\prime}$ South Latitude. The earthquake that occurred on the island of Flores is caused by Back Arc Thrust which stretches across the Flores Sea parallel to the archipelago of Bali and Nusa Tenggara in the form of segments, where there are major segments as well as minor segments. Back Art Thrust is a fault tectonic structure rising behind the arch of the archipelago. This structure is formed by the backlash of the Euresia plate against the Indo-Australian ocean plate. The phenomenon of arc-continent collision is thought to be the controller of this rising deformation mechanism. The western segmentation fault is known as the rising fault of Flores (Flores thrust) that stretches from northeast Bali to northern Flores. Flores Thrust is known as a destructive earthquake generator that will constantly threaten to shake the arch of the archipelago. This fault became very popular because on 12 December 1992 caused the Flores earthquake followed by tsunami tidal wave that killed 2,100 people. Eastern segmentation fault is known as Wetar rising fault (Wetar thrust) that stretches from north of Alor island to Romang island. This structure is no less dangerous than Flores thrust in terms of producing large earthquakes and damaging the area of NTT. Estimating an aftershocks needs to be done to reduce material losses caused by the earthquake. By conducting Coulomb stress calculation then it can be estimated the potential areas for aftershocks occurrence.

\footnotetext{
${ }^{1}$ Emanuel Destianus Banggut and Bagus Jaya Santosa are with Department of Physics, Institut Teknologi Sepuluh Nopember, Surabaya, 60111, Indonesia. E-mail: gnamotfisika@yahoo.co.id; bjs@physics.its.ac.id.
}

The Research about earthquake and volcano relation is done by Walter, et al. [1], in which the observation states that the occurrence of tectonic earthquakes around Merapi has proven to increase the extrusion of magma.

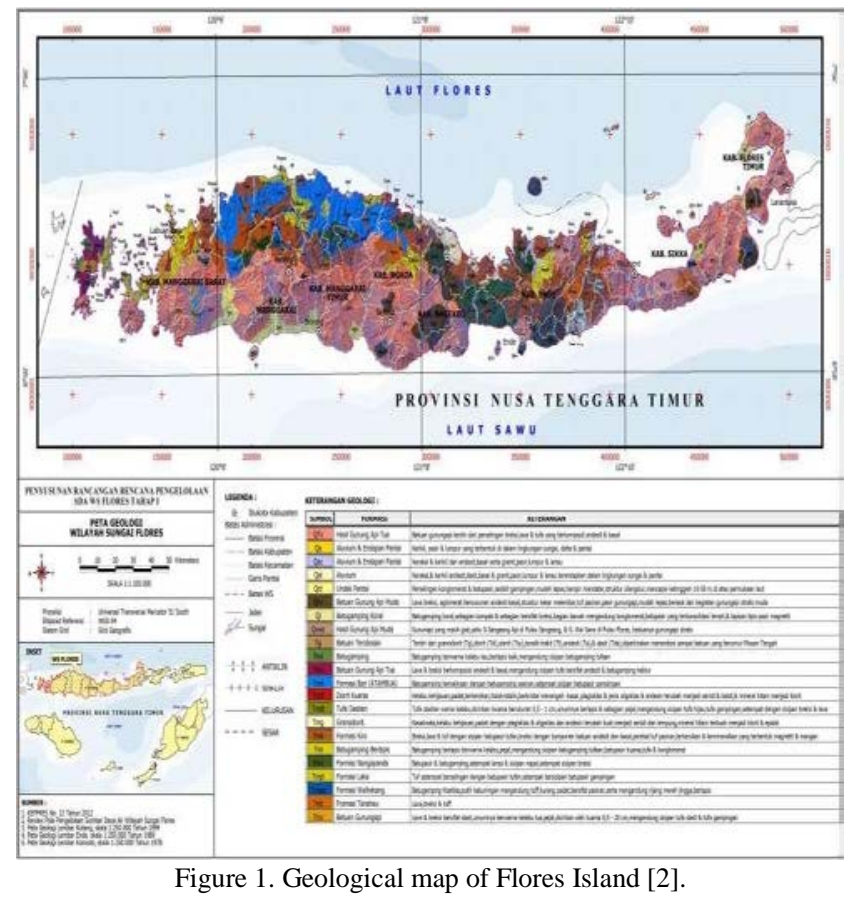

Figure 1 shows a geological map showing the rock structure of the island of Flores, which is generally igneous type. 


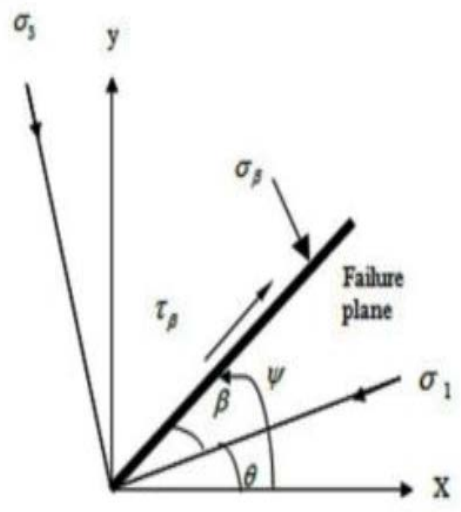

Figure 2. Coordinate system of static stress calculation [3], [4]

The coordinate system in Figure 2 shows the fractured plane subjected to normal stress and shear stress. The system shows the fault field that is subjected to normal stress or what is called the main stress component and the shear stress component in the fault field [5].

\section{METHOD}

This research used earthquake data obtained from BMKG site which can be seen at www.webdc.eu taken since 09-292012 to 04-02-2018. The data consist of earthquake events for at least 4.8 SR occurred on coordinates of $7.020^{\circ}$ $10,210^{\circ}$ South Latitude and $118,030^{\circ}$ - $124,750^{\circ}$ East Longitude. The downloaded data shown some earthquake parameters that include time, magnitude, and the location of the earthquake. Downloaded data is still in. SEED (Standard for Exchange of Earthquake Data) format. To be used in the next process then the data format should be changed in the form of format. SAC (Seismic Analysis Code). Furthermore, the data conducted by using Seisgram2K software to get the travel time of $\mathrm{P}$ and $\mathrm{S}$ wave. Then the data picking processed by using VELEST software to get model of local earth velocity. After getting local earth velocity model, data is processed by using ISOLA-GUI to get the focal mechanism form and moment tensor value of main earthquake. The result data from ISOLA-GUI were processed further by using coulomb stress software to estimate the area that experienced increase and decrease stress stress caused by main earthquake.

\section{RESULTS AND DISCUSSION}

Based on the result of Velest data processing obtained form model of local earth Flores:

$\begin{aligned} & \text { Crustal model } \\ & \text { number of layers }\end{aligned}$
$\begin{array}{ccl}14 & & \\ \text { Parameters of the layers } & & \\ \text { Pap-S } \\ \text { depth of layer top }(\mathrm{km}) & \text { Vp }(\mathrm{km} / \mathrm{s}) & \text { Vs }(\mathrm{km} / \mathrm{s}) \\ 0.0 & 2.320 & 1.350 \\ 1.0 & 4.190 & 2.190 \\ 2.0 & 5.420 & 2.700 \\ 5.0 & 5.970 & 2.700 \\ 16.0 & 5.970 & 3.970 \\ 33.0 & 5.970 & 5.190 \\ 40.0 & 9.870 & 5.250 \\ 100.0 & 10.050 & 5.400 \\ 225.0 & 11.590 & 5.400 \\ 325.0 & 11.600 & 5.460 \\ 425.0 & 11.620 & 5.470 \\ 460.0 & 11.620 & 6.290 \\ 510.0 & 11.620 & 7.940 \\ 610.0 & 11.640 & 7.960\end{array}$

Figure 3. Local Earth velocity model.

In figure 3, number 14 shows the number of layers, and the numbers 0.0 to 610 indicate the depth of the layer. Whereas VP is the primary wave velocity and VS is the secondary wave velocity. The control of this method is the conformity of the seism tectonic conditions of the study and the minimum error value (RMS), the smaller of RMS value is the better. [6], [7] When obtaining the local earth model by looking at the RMS value of each earthquake event in general $<1$, then the next data processing to get the model of the beach ball, moment tensor, synthetic wave form and observation of each station and dip, strike and rake value, as seen in the picture below.
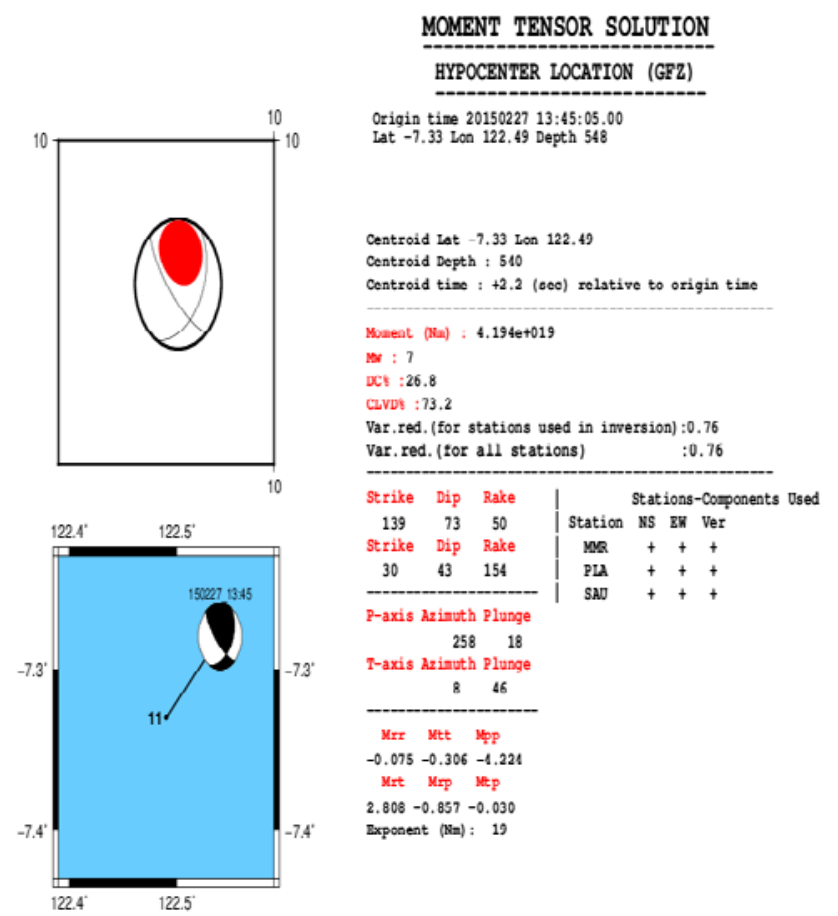

Figure 4. Results of ISOLA-GUI processing.

Figure 4 shows that there are three seismic stations, namely MMR, PLA and SAV 1 which result from processing ISOLA data, the reduction variance value is 
$0.76(76 \%)$. It means that the results of processing this data can be used as a reference for further data processing.

In addition, there are strike values, dip and rake. Strike is a line formed from the intersection of a planar plane with a horizontal plane viewed from the north; DIP is the degree of slope formed between planar and horizontal planes perpendicular to the strike line; rake is the angle formed by strike and DIP.

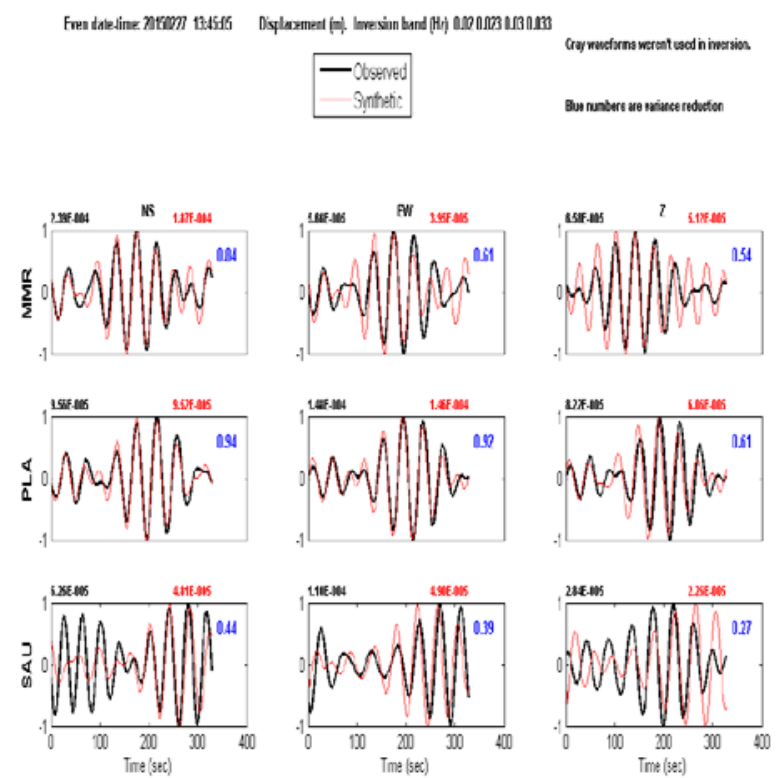

Figure 5. Wave form synthetic vs observation.

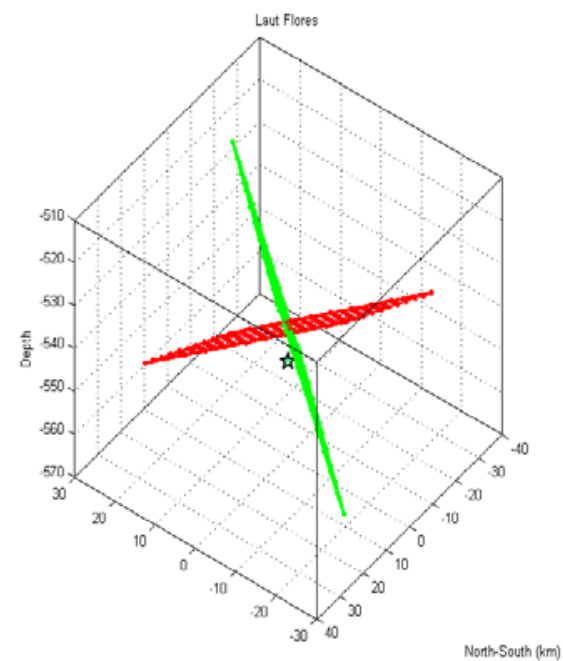

East:West (km)

Figure 6. Result of HC-PLOT

The control of this method is the value of the reduction variance. The value of the reduction variance is the percentage of fitting waveform observation with synthetic waveform. Good fittings could be indicated from a variance value greater than $65 \%$ [8]. From the results of ISOLA above can be seen that the value of reduction variance of $76 \%$. This indicates that the 3 earthquake stations used give almost the same waveform. Based on the result of data processing above obtained by focal mechanism of earthquake of 27-02-2015 is oblique reverse with values as follows:

TABLE 1.

THE EARTHQUAKE VALUE MOMENT TENSOR COMPONENT BY EVENT 27-022015.

\begin{tabular}{lcccccc}
\hline \hline \multicolumn{1}{c}{ Event } & Mrr & Mtt & Mpp & Mrt & Mrp & Mtp \\
\hline $\begin{array}{l}\text { 2015-02-27 } \\
\text { 13:45:05 }\end{array}$ & -0.075 & -0.306 & -4.224 & 2.808 & -0.857 & -0.030 \\
\hline \hline
\end{tabular}

TABLE 2.

VALUE OF STRIKE, DIP, DAN RAKE.

\begin{tabular}{lllllll}
\hline \hline \multirow{2}{*}{ Event } & \multicolumn{3}{c}{ Plane I } & \multicolumn{3}{c}{ Plane II } \\
\cline { 2 - 7 } & Strike & Dip & Rake & Strike & Dip & Rake \\
\hline $\begin{array}{l}\text { 2015-02-27 } \\
\text { 13:45:05 }\end{array}$ & 139 & 73 & 50 & 30 & 43 & 154 \\
\hline \hline
\end{tabular}

TABLE 3.

LENGTH AND WIDTH OF FAULT PLANE.

\begin{tabular}{lcc}
\hline \hline \multicolumn{1}{c}{ Event } & Length (km) & Width (km) \\
\hline $\begin{array}{l}\text { 2015-0227 } \\
\text { 13:45:05 }\end{array}$ & 43.65 & 18.19 \\
\hline \hline
\end{tabular}

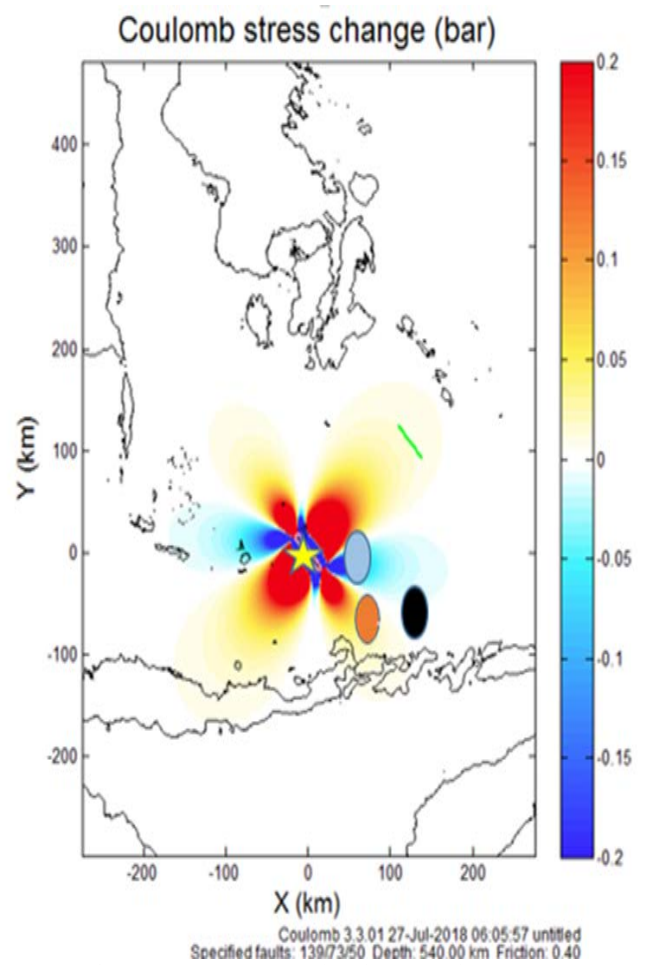

Figure 7. Output Coulomb Stress by event 27-02-2015.

Information:

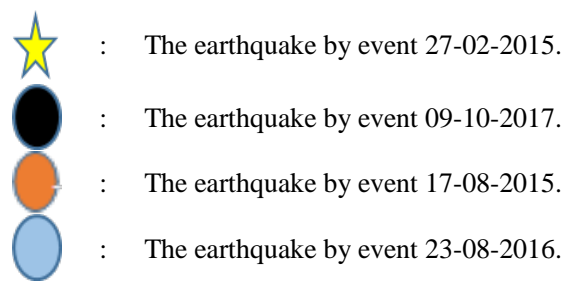

Based on results of Coulomb Stress below can be seen that the red lobes that have pressure exceeds 0.2 bar, the effect is not too reaching the island of Flores so that the 
impact is not too harmful. And the effects of this quake provide the possibility of aftershocks that may not be too large energy. If you see the earthquake data in the webdc catalog, there are some earthquake events that occur in the north of Flores but in a small magnitude scale. This may be the effect of residual stresses due to regions entering the red lobe region. However, there is still a lower left lobe area that has not provided an earthquake with a scale of $4.8 \mathrm{SR}$, which this area should be anticipated in order for an earthquake to not cause severe damage.

\section{Conclusion}

Based on the above results it can be concluded:

1. The focal mechanism of Earthquake 27-02-2015 has a reverse focal mechanism oblique with nodal plane I: strike 139, dip 73 and rake 50. While the nodal plane II: strike 30, dip 43, and rake 154 .

2. Based on the results of Coulomb stress change, due to the main earthquake caused changes in pressure in areas of aftershocks are:

a. The area of the earthquake of 17-08-2015 experienced an increase in Coulomb pressure of $0.1-0.15$ bar.

b. The earthquake dated 23-08-2016 some areas experienced an increase in Coulomb pressure of 0.15 to $0.2 \mathrm{bar}$ and other areas decreased from 0.15 to 0.2 bar.

c. Earthquake area dated 09-10-2017 some areas decreased Coulomb pressure of 0.05 - 0.1 bar.

\section{ACKNOWLEDGEMENTS}

Acknowledgements and appreciations are given to LPDP (Institute of Education Fund Management), Ministry of finance of the Republic of Indonesia which has provided education and research funds, so this research can be done well.

\section{REFERENCES}

[1] T. R. Walter, R. Wang, M. Zimmer, H. Grosser, B. Lühr, and A. Ratdomopurbo, "Volcanic activity influenced by tectonic earthquakes: Static and dynamic stress triggering at Mt. Merapi,” Geophys. Res. Lett., vol. 34, no. 5, pp. 1-5, Mar. 2007.

[2] “No Title.” [Online]. Available: www.bnpb.go.id/bpbd-provinsinusa-tenggara-timur.

[3] F. Puspasari and W. Wahyudi, "Distribusi coulomb stress akibat gempabumi tektonik selatan Pulau Jawa berdasarkan data gempa tektonik 1977-2000,” J. Fis. dan Apl., vol. 13, no. 2, p. 74, Jun. 2017.

[4] Geoffrey C. P., R. S. Stein, and J. Lin, "Static stress changes and the triggering of earthquakes,” Bull. Seismol. Soc. Am., vol. 84, no. 3, pp. 935-953, Jun. 1994.

[5] S. Ardiansyah, "Sabar Ardiansyah," SIMETRI, J. Ilmu Fis. Indones., vol. 2, no. 1, pp. 2102-10, 2014.

[6] E. Kissling, U. Kradolfer, and H. Maurer, "Velest user's guide Short Introduction." Institute of Geophysics and Swiss Seismological Service, ETH-Hoenggerberg, Zurich, 1995.

[7] M. Madlazim and B. J. Santosa, "Simultaneous inversion for 1D PWave velocity model, station correction and hypocenters of Sumatran earthquakes," in Proceedings 5th Kentingan Physics Forum, 2010, pp. 93-93.

[8] Madlazim and J.S. Bagus, "Estimasi Parameter Sumber Gempa Bumi Padang 30 September 2009 , Mw $=7$, 6 dan Korelasinya dengan Aftershocks-nya,” J. Mat. Sains, vol. 19, no. 3, pp. 86-91, 2014. 